\title{
Molecular signatures of Janthinobacterium lividum from Trinidad support high potential for crude oil metabolism
}

\author{
Amanda C. Ramdass and Sephra N. Rampersad"(i)
}

\begin{abstract}
Background: Janthinobacterium lividum is considered to be a psychrotrophic bacterial species. For the first time in the literature, J. lividum strains were isolated from Trinidad presenting with atypical features - hydrocarbonoclastic and able to survive in a tropical environment.

Methods: Identification of the Trinidad strains was carried out through 165 rRNA phylogenetic analysis. Gene-specific primers were designed to target the VioA which encodes violacein pigment and the EstA/B gene which encodes secreted extracellular lipase. Bioinformatics analyses were carried out on the nucleotide and amino acid sequences of $V i O A$ and $E s t A / B$ genes of the Trinidad Janthinobacterium strains to assess functionality and phylogenetic relatedness to other Janthinobacterium sequences specifically and more broadly, to other members of the Oxalobacteraceae family of betaproteobacteria.
\end{abstract}

Results: $16 \mathrm{~S}$ rRNA confirmed the identity of the Trinidad strains as J. lividum and resolved three of the Trinidad strains at the intra-specific level. Typical motility patterns of this species were recorded. VioAp sequences were highly conserved, however, synonymous substitutions located outside of the critical sites for enzyme function were detected for the Trinidad strains. Comparisons with PDB $6 \mathrm{~g} 2 \mathrm{p}$ model from aa231 to aa406 further indicated no functional disruption of the VioA gene of the Trinidad strains. Phylogeny of the VioA protein sequences inferred placement of all J. lividum taxa into a highly supported species-specific clade (bs=98\%). EstA/Bp sequences were highly conserved, however, synonymous substitutions were detected that were unique to the Trinidad strains. Phylogenetic inference positioned the Trinidad consensus VioA and EstA protein sequences in a clearly distinct branch.

Conclusions: The findings showed that the primary sequence of VioAp and EstA/Bp were unique to the Trinidad strains and these molecular signatures were reflected in phylogenetic inference. Our results supported chemotaxis, possible elective inactivation of VioA gene expression and secreted lipase activity as survival mechanisms of the Trinidad strains in petrogenic conditions.

Keywords: Janthinobacterium lividum, L-tryptophan oxidase, Lipase phylogeny, Violacein

*Correspondence: sephra.rampersad@sta.uwi.edu

Biochemistry Research Lab (Rm216), Department of Life Sciences,

Faculty of Science and Technology, The University of the West Indies, St.

Augustine, Trinidad and Tobago

\begin{abstract}
Background
Diverse hydrocarbonoclastic bacteria, have demonstrated the capacity to degrade hydrocarbons [1, 2], and their biochemical and ecological features should be explored further $[3,4]$. Some bacteria possess a contradictory response to these pollutants; they can mineralize chemical compounds for growth but, when aromatic
\end{abstract}


compounds exceed toxicity thresholds, derangement of structural and functional properties of their membranes occurs followed by death [5]. In response to changing environments, motile bacteria can navigate through micro-environments to locate metabolizable compounds for growth and survival, and avoid sites of low nutrient availability, through complex metabolism-dependent and independent chemotaxis [6-12].

Janthinobacterium lividum belongs to the family Oxalobacteraceae. This family comprises 13 genera [13], whose membership consists of J. lividum [14], J. svalbardensis [15], and J. agaricidamnosum [16] as well as the recently reported $J$. violaceinigrum sp. nov., J. aquaticum sp. nov., and J. rivuli sp. nov. [17]. Janthinobacterium species are Gram-negative, motile, rod-shaped, strictly aerobic, chemoorganotrophic, and usually grow at a temperature optimum of $25-30^{\circ} \mathrm{C}$ which is typical of mesophiles [13]; however, psychrophilic strains can grow at $4{ }^{\circ} \mathrm{C}$ [18]. Although Janthinobacterium strains have been isolated from soil [19-21], they are more commonly found in various aquatic habitats [18, 21-23], including the skin of amphibians [24, 25], and rainbow trout [26].

J. lividum colonies can be purple-violet in color as a result of production of the pigment, violacein [19, 27-29]. Biosynthesis of violacein, under favourable conditions, is enabled through activation of an operon, $V i o A B C D E$, whose expression is regulated by the type of carbon source [30]. The first committed step in violacein production is catalysed by the protein product of VioA, L-tryptophan oxidase [30-33]. Reports of nonpigmented and partly pigmented C. violaceum, and J. lividum strains also suggest that violacein production may not be a reliable taxonomic characteristic [34]. In general, pigments produced by bacteria are important for protection against other bacteria, ultraviolet radiation, oxidants, extreme temperature, and desiccation [35-38]. However, the specific role of violacein in J. lividum strains, and the reason for elective inactivation of the Vio operon in nonpigmented strains are unknown.

Among the microbial enzymes that can mineralize certain hydrocarbons (e.g. polycyclic aromatic hydrocarbons - PAHs), lipases are one of the largest groups of commercially important enzymes (ranked third after proteases and carbohydrates) due to their diversity and versatility [12, 39-44]. Microbes produce lipases (E.C.3.1.1.3 - triacylglycerol acyl hydrolases) that act at the interface generated by a hydrophobic lipid substrate in a hydrophilic aqueous medium. In the case of oil-contaminated environments, secreted lipases play a critical part in inducing lipolytic reactions of emulsified hydrocarbons at the lipid-water interface which assists in hydrocarbon uptake by adapted microbes [45-49].
In Trinidad, J. lividum has been isolated from several chronically polluted sites in the southern part of the island where petrogenic mud volcanoes, natural oil seeps and leaking above-ground oil conduit pipelines are common to the landscape [50]. Initial assessments pointed to identification of these Trinidad strains as J. lividum based on 16S rRNA sequence comparisons, specifically via the $16 \mathrm{~S}$ rRNA Blast server. The Trinidad strains presented with atypical features not been previously cited in the literature i.e. their oil-contaminated natural habitat, low oxygen availability in such soils that must limit the survival of these strict aerobes, they were only isolated from crude oil-contaminated soil with temperatures at or above $45^{\circ} \mathrm{C}$, and were only recovered as the sole bacterial member of naturally-occurring consortia with different yeast species. But, in culture, these Trinidad strains are highly efficient at crude oil degradation [50]. There are no previous reports of J. lividum inhabiting oil-contaminated terrestrial environments or other literature that describe a high capability to metabolize crude oil. Additionally, the Trinidad strains did not produce violacein in culture, despite several attempts to induce biosynthesis based on the findings of Pantanella et al. [38]. All of these strain-specific features challenge some of the more common assumptions associated with characterising $J$. lividum species based on phenotype.

Based on the foregoing, we took a targeted gene approach to understanding how these Trinidad J. lividum strains survive. The phylogenetic relationships of these Trinidad strains with closely related Gram-negative members of the Oxalobacteraceae family were assessed based on 16S rRNA phylogeny. To understand the lack of pigmentation of the Trinidad strains, we designed species- and gene-specific primers that target the VioA gene, and conducted comparative analysis of the nucleotide (nt) and amino acid (aa) sequences of this gene with other J. lividum strains, and other violacein pigment-producing species. Further, to determine how survival is affected by the ability of the Trinidad strains to secrete lipase in the lipolytic catalysis of crude oil, we focused on the detection of the EstA/B gene in Trinidad Janthinobacterium isolates by designing species- and gene-specific primers, and analysed the nt and aa sequences of this gene compared with $E s t A / B$ of other strains and species. Motility of all strains from Trinidad was also assessed. The findings of this work provided the first molecular insight into atypical oil-degrading J. lividum strains from Trinidad.

\section{Results}

Motility of Trinidad J. lividum strains

A video demonstrating the motility of Trinidad J. lividum strains has been submitted to the journal. 


\section{$16 \mathrm{~S}$ rRNA analysis}

The best substitution model $(\mathrm{JC}+\mathrm{G})$ was determined in MEGAX and the corresponding 50\% bootstrap consensus Maximum Likelihood (ML) tree is presented (Fig. 1). The tree was rooted with Burkholderia cepacia strain PRS [34]. Trinidad strains were placed into the J. lividum clade. A sub-clade consisted of Duganella and Massilini members with moderate bootstrap support $(\mathrm{bs}=65 \%)$. Some inter-specific sequence divergence was evident for members of the Duganella and Massilini clades. Distinct clades with high bootstrap support were obtained for Oxalicibacterium, Chromobacterium, and Herminiimonas species. High bootstrap support was also indicated for the Chromobacterium clade (bs $=99 \%$ ). The $J$. lividum clade revealed polytomic branching for most taxa which was indicative of very low to no $16 \mathrm{~S}$ rRNA sequence divergence for this species, and which confirmed the identity of the Trinidad isolates as J. lividum based on the assumption that sequences with 97\% identity represent the same species [51]. 16S rRNA phylogenetic inference also revealed that placement of taxa was largely based on species, and there was no evidence of clustering according to geography or source of origin. $16 \mathrm{~S}$ rRNA phylogeny was also able to resolve three (F2TT1, V4TT2 and V1TT1) out of the 20 Trinidad strains at the intra-specific level.

\section{VioA nucleotide and amino acid sequence analyses}

VioA must be activated to begin biosynthesis of violacein, and for this reason, the VioA gene of the Vio$A B C D E$ operon (Fig. 2) was the focus of this study. Blastn and Blastp comparisons gave the highest probable identity of the nt and aa VioA sequences of the Trinidad strains as L-tryptophan oxidase which is an FAD-dependent amino-oxidoreductase. Sequence comparisons of the Trinidad strains as violacein-nonproducers were carried out with a published violaceinproducer (J. lividum strain JF266634 from Antarctica) [52, 53], and with a published C. violaceum strain ATCC $12472[54,55]$. A high level of conservation was indicated by alignments of $V i o A$ aa sequences. The aligned $V i o A$ aa sequences are shown in Fig. 3.

A comparison of the consensus aa sequence of the Trinidad strains (violacein non-producers) with violacein-producer J. lividum strain JF266634 revealed specific aa substitutions at positions outside of the FADbinding site, outside of the L-tryptophan-binding site, and thus, outside the critical sites for enzyme function. The aa substitutions detected in the Trinidad consensus sequence were all predicted to be neutral according to analysis conducted on the PROVEAN (Protein Variation Effect Analyzer) server [57, 58], with a threshold predictor score $>-2.5$. Further confirmatory analysis of these positions with mutagenesis studies of catalytic residues of C. violaceum strain ATCC 12472 revealed that all residues that are required for binding of the FAD cofactor and L-tryptophan substrate were absolutely conserved in the Trinidad strains. Hence, all critical sites were highly conserved. Two additional binding sites (located at aa16 and aa240) associated with $\mathrm{Mg}^{2+}$ metal binding as reported for C. violaceum strain ATCC 12472 in UniProtKB (Q9S3V1) [59], were also conserved for Trinidad strains, and for J. lividum JF266634. The aligned VioA aa consensus sequence of the Trinidad strains with that of JF266634 is shown in Fig. 4.

Examination of the PDB 6g2p model, which included 418 amino acid residues, revealed consensus of all binding sites in the sequences compared in this study. The Trinidad consensus sequence and JF266634 sequence aligned with the PDB model from aa231 to aa406. These analyses indicate no functional disruption of the VioA gene of the Trinidad strains.

\section{VioA protein tree}

Deduced VioA protein sequences of all J. lividum taxa, including Trinidad consensus protein sequence, were placed into a highly supported clade $(b s=98 \%)$. Other highly supported clades were species-specific (Fig. 5).

\section{EstA/B (Alpha beta-hydrolase) nucleotide and amino acid sequence comparisons}

The order of amino acids in the consensus protein sequence of the Trinidad strains formed structural domains indicative of hydrolytic enzymes with a characteristic alpha/beta fold. The ESTHER database (ESTerases and alpha/beta-Hydrolase Enzymes and Relatives) [60] also confirmed these features. The EstA/B protein sequences fold to produce "a catalytic triad", which represent the highest conserved structural features of the fold.

\section{(See figure on next page.)}

Fig. 1 Molecular phylogenetic analysis by Maximum Likelihood method 16S rRNA. The evolutionary history was inferred by using the ML method based on the Jukes-Cantor model. The tree with the highest log likelihood (0.0000) is shown. The percentage of trees in which the associated taxa clustered together is shown next to the branches. Initial tree(s) for the heuristic search were obtained by applying the Neighbor-Joining method to a matrix of pairwise distances estimated using the Maximum Composite Likelihood (MCL) approach. A discrete Gamma distribution was used to model evolutionary rate differences among sites ( 6 categories $(+G$, parameter $=0.4823)$ ). The tree is drawn to scale, with branch lengths measured in the number of substitutions per site. The analysis involved 106 nucleotide sequences. All positions containing gaps and missing data were eliminated. There were a total of 735 positions in the final dataset. Evolutionary analyses were conducted in MEGAX 
Janthinobacterium lividum F2TT4

Janthinobacterium lividum F2TT10

Janthinobacterium lividum SNU4 (MK757612)

Janthinobacterium lividum PTT1

Janthinobacterium lividum F1TT11

Janthinobacterium lividum S8 (LK391529)

Janthinobacterium lividum IHBB 11033 (KR085902)

Janthinobacterium lividum IN230 (KT923309)

Janthinobacterium lividum 25 JR12 (LT547844)

Janthinobacterium lividum LMG 3918 (MF979544)

Janthinobacterium lividum 173 (MF777041)

Janthinobacterium lividum SNU4 (MK757612)
Janthinobacterium lividum EXB-L-1993 (MN334236)

Janthinobacterium lividum EXB-L-1993

Janthinobacterium lividum MTT38

Janthinobacterium lividum A15CS2014 (KP762193)
Janthinobacterium lividum IHBB 9166 (KR085802)

Janthinobacterium lividum IHBB 9166 (KR085802)
Janthinobacterium lividum 4S B2 8 CS2014 (KP762228)

Janthinobacterium lividum 4S B2 8CS2014 (KPT6

Janthinobacterium lividum CM37 (AY247410)
Janthinobacterium lividum K172 (KRO88420)

Janthinobacterium lividum DT63-3 (KC920945)

Janthinobacterium lividum IHB B 6464 (KR233788)

Janthinobacterium lividum XT1 (EU642885)

Janthinobacterium lividum SQ66 (KC920976)

Janthinobacterium lividum RBE1CD-85 (EF111127)

Janthinobacterium lividum HC-3 (KF993615)

Janthinobacterium lividum C12 (KT767718)

Janthinobacterium lividum CLU 25 (IF970593)

Janthinobacterium lividum ATCC 33665 (AB021388)

Janthinobacterium lividum S8 (LK391529)

Janthinobacterium lividum IHBB 11033 (KR085902)

Janthinobacterium lividum IN230 (KT923309)

Janthinobacterium lividum KOPRI 25541 (HQ824838)

Janthinobacterium lividum PRO3 (DQ640007)

Janthinobacterium lividum NBRC 12613 (AB680301)

Janthinobacterium lividum BPO1 (EU330449)

Janthinobacterium lividum BD17-1 (AF174648)

Janthinobacterium lividum IARI-RP3 (KF712914)

Janthinobacterium lividum JPB-1.17a (EU652474)

Janthinobacterium lividum DSM 1522 T (Y08846)

Janthinobacterium svalbardensis strain JA-1 (NR 132608)

Janthinobacterium lividum $\mathrm{CH} 7-13$ (KC855475)

Janthinobacterium lividum OW6-RT-3 (EF523603)
Janthinobacterium sp. ERGS5:01 (KT766048)

Janthinobacterium lividum V4TT3

Janthinobacterium lividum V5TT2

Janthinobacterium lividum F1TT8

Janthinobacterium lividum F1TT10

Janthinobacterium lividum F2TT9

anthinobacterium lividum F1TT12

Janthinobacterium lividum F2TT8

Janthinobacterium lividum F2TT6

Janthinobacterium lividum F2TT6

Janthinobacterium lividum KB51 (JF327475)

Janthinobacterium lividum B26.7 (JN662543)

Janthinobacterium lividum IARIR-50 (JX429043)

anthinobacterium lividum FVB1 (AB428446)

Janthinobacterium lividum LE 95 (FN908445)

Janthinobacterium lividum YF11-3(4) (KT369907)

Janthinobacterium sp. FT YF (MW33292)

(iviaum MTR (JQ070957)

- Janthinobacterium lividum F2TT1

- Janthinobacterium lividum V4TT2

Janthinobacterium lividum V1TT1

anthinobacterium lividum A1CS2014 (KP762181)

Janthinobacterium lividum F2TT5

anthinobacterium lividum RBE1CD-64 (EF111116)

Janthinobacterium violaceinigrum FT13W (NR 170541)

Janthinobacterium aquaticum MTS W (NR 77539 )

Janthinobacterium lividum MMP4 (KF990995)

anthinobacterium lividum GAO1 (DO473538)

anthinobacterium lividum JN111 (KF150395)

Janthinobacterium lividum B21 (LN890197)

anthinobacterium lividum Acam (EU275366)

Janthinobacterium Lividum 2B1 (KJ589455)

Janthinobacterium lividum A31 (KT767666)

69 . Massilia atriviolacea SOD (NR 171529)

Massilia glaciei B448-2 (NR 158142)

Duganella levis CY42W (NR 170535)

[- Duganella pernnla FT109W (NR 170536 )

Duganella phyllosphaerae T54 (NR 117042)

- Duganella albus FT9W (NR 170532)

128 Massilla buxea A9 (NR 159161)

97 Lassilla aquatica Fri27W (NR 170542)

4 Duganella fentianensis FTS WR (NR N

95. Duganella qianjladongensis CY13W (NR 170537)

Janthinobacterium agaricidamnosum NBRC 102515 (NR 114134)

93 Janthinobacterium agaricidamnosum NBRC

Janthinobacterium lividum P-20 (KF318409)

Herminiumonas arsenicoxydans ULPAS7 (NR
Herminimonas glaciei UMB49 (NR 044508)

94. Herminilimonas glaciei UMB49 (NR 044508)

Chromobacterium violaceum NBRC 12614 (NR 113595)
Chromobacterium violaceum ICM 1249 (NR 113239)

99 Chromobacterium violaceum LMG 3953 (NR 113239)

99 Chromobacterium violaceum ATCC 12472 (NR 074222)

Burkholderia cepacia PRS (LT844653)

Fig. 1 (See legend on previous page.) 


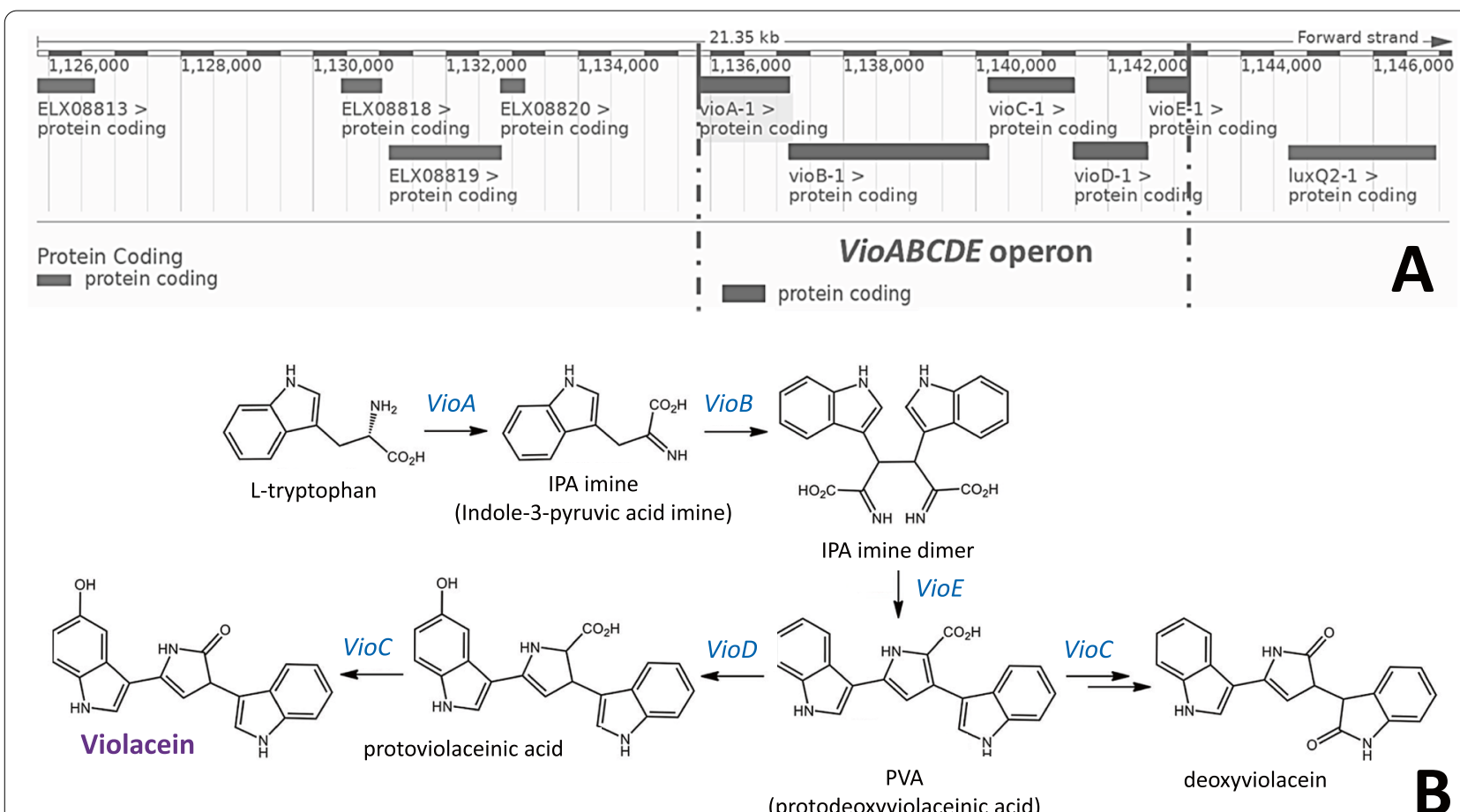

Fig. 2 Violacein biosynthesis. A Biosynthetic gene cluster of VioABCDE operon of Janthinobacterium lividum GCA 900451145 (Gene ID: NCTC9796_03462) [56] that code for key enzymes in the five-step biosynthesis of violacein. B Biosynthetic pathway of violacein production. VioA encodes L-tryptophan oxidase which is the first enzyme required for IPA imine formation; this enzyme functions with an FAD Co-factor. The VioB gene encodes an oxidase with a heme moiety, then utilizes IPA imine intermediate as a substrate to form the IPA imine dimer. The VioE-encoded enzyme in turn uses the dimer as a substrate, transforming it into intermediates for use by VioD and VioC-encoded enzymes. VioD and VioC encode FAD dependent-monooxygenases and both lead to the formation of violacein and deoxyviolacein

These enzymes have diverged from a common ancestor to preserve the arrangement of the catalytic residues, and not necessarily the binding site, which indicates substrate diversity for this enzyme class. Those aa sequences that lack one or all of the catalytic residues are, therefore, inactive. The aa sequence of the Trinidad strains belonged to the CATH Superfamily 3.40.50.1820 [56].

A comparison of $200 E s t A / B$ aa sequences revealed high conservation, particularly one invariant block, "VAHSMGGANTL" located at aa74 to aa84, and which was present in all 200 reference sequences which included Bacillus species, and the consensus sequence of the Trinidad J. lividum strains. This block was also the longest length of conserved aa in the protein sequence. The conserved and variable aa positions in the consensus protein sequence of the Trinidad strains compared with two other reference sequences are illustrated in Fig. 6.

A search of UniProtKB confirmed the subcellular location of the consensus $E s t A / B$ aa sequence of the Trinidad strains as extracellular, and both the ESTHER and UniProtKB databases confirmed the presence of characteristic domain features of a signal peptide and transmembrane region which are both required for secretion of this enzyme to the extracellular environment.

PROVEAN indicated that the aa substitutions in the Trinidad EstA/B consensus sequence were predicted to be neutral based on a threshold variant score $>-2.5$. Thus, the nt substitutions of the Trinidad strains were synonymous, and had no effect on the primary structure of the enzyme.

A comparison of the genomic region in Patric 3.6.9 (Pathosystems Resource Integration Center; https://www.patricbrc. org/) [61] indicated conserved genomic organization and synteny of this gene among six species that belonged to the Janthinobacterium genus. Regions that flanked this gene differed in sequence and gene product.

\section{EstA protein tree}

Phylogenetic inference based on deduced protein sequence of the EstA gene indicated aa variation for the majority of the taxa indicated by bifurcating branches, however, there was a single polytomic branch that consisted of three taxa which was highly supported (bs $=99 \%$ ). The Trinidad consensus EstA protein 

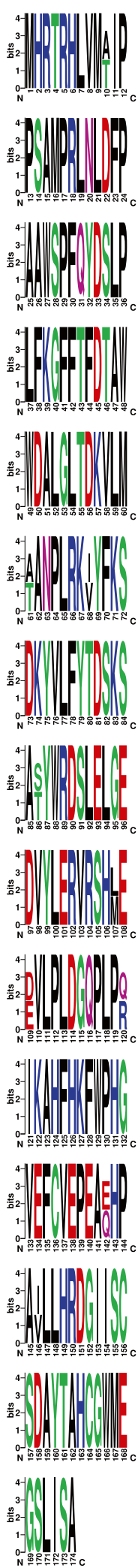

Fig. 3 Weblogo illustration of aligned VioA amino acid sequences belonging to 40 different bacterial species including VioA consensus sequence of Trinidad strains

sequence was positioned in a distinct branch with moderate boot strap support (62\%) (Fig. 7).

\section{Discussion}

16S rRNA phylogeny positioned the Trinidad J. lividum strains in a strongly-supported species-specific clade and sequence similarity among other Janthinobacterium species was above the recommended identity threshold. There was also polytomic branching among the $J$. lividum species indicative of low $16 \mathrm{~S}$ rRNA sequence variation among of majority of those taxa belonging to this clade. The $16 \mathrm{~S}$ rRNA gene sequence was, therefore, unable to resolve intraspecies variability. Similar findings were reported by [62-65]. Colony morphology or $16 \mathrm{~S}$ rRNA gene sequence alone may not always accurately represent taxonomy of this species [66].

J. lividum is commonly isolated from aquatic and temperate environments [67] and as such, must be able to navigate and explore their habitats. Motility enables cells to sequester essential resources more efficiently and avoid low-nutrient areas in a highly competitive environment [68]. For the first time, $J$. lividum was isolated from terrestrial natural crude oil seeps and an asphaltic mud volcano in Trinidad and the strains were confirmed to be motile in this study. Motility in such terrestrial environments may be explained by the ability of this bacterial species to rely on gradient-guided swimming (chemotaxis) in a heterogeneous soil matrix [69]. Trinidad J. lividum strains inhabit non-water-saturated, petrogenic soil, and as such, have an adaptive need for energetically-expensive motility. Flagellar motility, including swarming [69], in unsaturated soils is restricted to saturation events, which are often short and sporadic e.g. rainfall and formation of rivulets that increase connectedness by creating micrometric aqueous films that may be thin and patchy. This would facilitate improved dispersal, and hence access to novel carbon sources but on a restricted scale. Motility can also lead to fitness gains conferred by fast surface colonization during transient wet periods which may, in part, explain the sustained presence of flagellated prokaryotes in partially saturated habitats such as soil surfaces [70].

Additionally, bacteria can disperse along fungal hyphae, which create "fungal highways" [71-78] through 

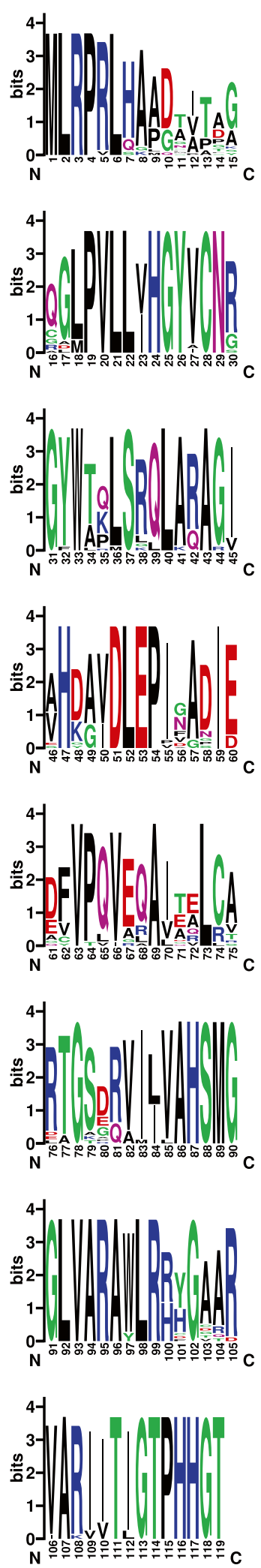

Fig. 4 Weblogo illustration of aligned VioA amino acid consensus sequence of the Trinidad strains, non-violacein producer, with that of JF266634, violacein-producer

air spaces in unsaturated soil. Hydrophilic hyphae grow through air pockets in the soil and the liquid film present around hyphae allows bacteria to disperse over air-filled soil spaces $[71,75]$. Bacterial motility via mycelium-associated dispersal helps to explain the persistence of flagellar motility in non-water-saturated environments [77], including oil-contaminated terrain [78].

The VioA gene of the VioABCDE operon was detected in non-violacein-producing Trinidad J. lividum strains. A non-violacein producing strain of J. lividum has also been reported by Kumar et al. [34], however, no VioABCDE operon was detected in whole genome sequence analysis. Friedrich et al. [79] described high nucleotide sequence conservation of the VioABCDE operon in a number of different $J$. lividum strains and reported conservation of this genomic block at the intraspecific level only. Our analyses indicated species-specific resolution with no evidence of functional disruption of the $V i o A$ gene product of the Trinidad strains. Similarly, Choi et al. [80] reported species-based placement of taxa for their VioA nucleotide sequence analysis. It is possible that the absence of violacein pigment in culture may be the result of operon inactivation due to missing induction signals [81]. Elective inactivation of this $\mathrm{VioA}$ gene is likely a consequence of co-metabolic synergy of Trinidad J. lividum strains with different yeast species for survival. Similar findings of multi-layered regulation of bacterial biosynthetic operons as an adapted regulatory response in relation to fluctuating, competitive and frequently stressful growth conditions were reported by Bervoets and Charlier [82].

The absence of violacein production in the Trinidad J. lividum strains can also be explained by the fact that they were only co-isolated with different species of yeast. Quorum sensing (QS) plays an important role in crosskingdom signalling, and molecular dialogue in this specific type of microbial consortia [83-85]. The genes of the VioABCDE operon have all been identified as QSdependent genes according to Haack et al. [23]. Based on the results of that study, the "janthinobacterial autoinducer (JAI-1)" affects the violacein biosynthesis in J. lividum strain HH01 [33] which in turn, affects cell-cell as well as intra- and inter-species communication. Absence of this JAI-1 signalling molecule reduces the level of inhibition of fungal growth. The Trinidad J. lividum strains existed in co-culture with different species of yeast in their natural habitat. Our findings suggest that it is worth investigating the genetic and biological basis of J. lividum strains that elect to repress expression of this operon as a 


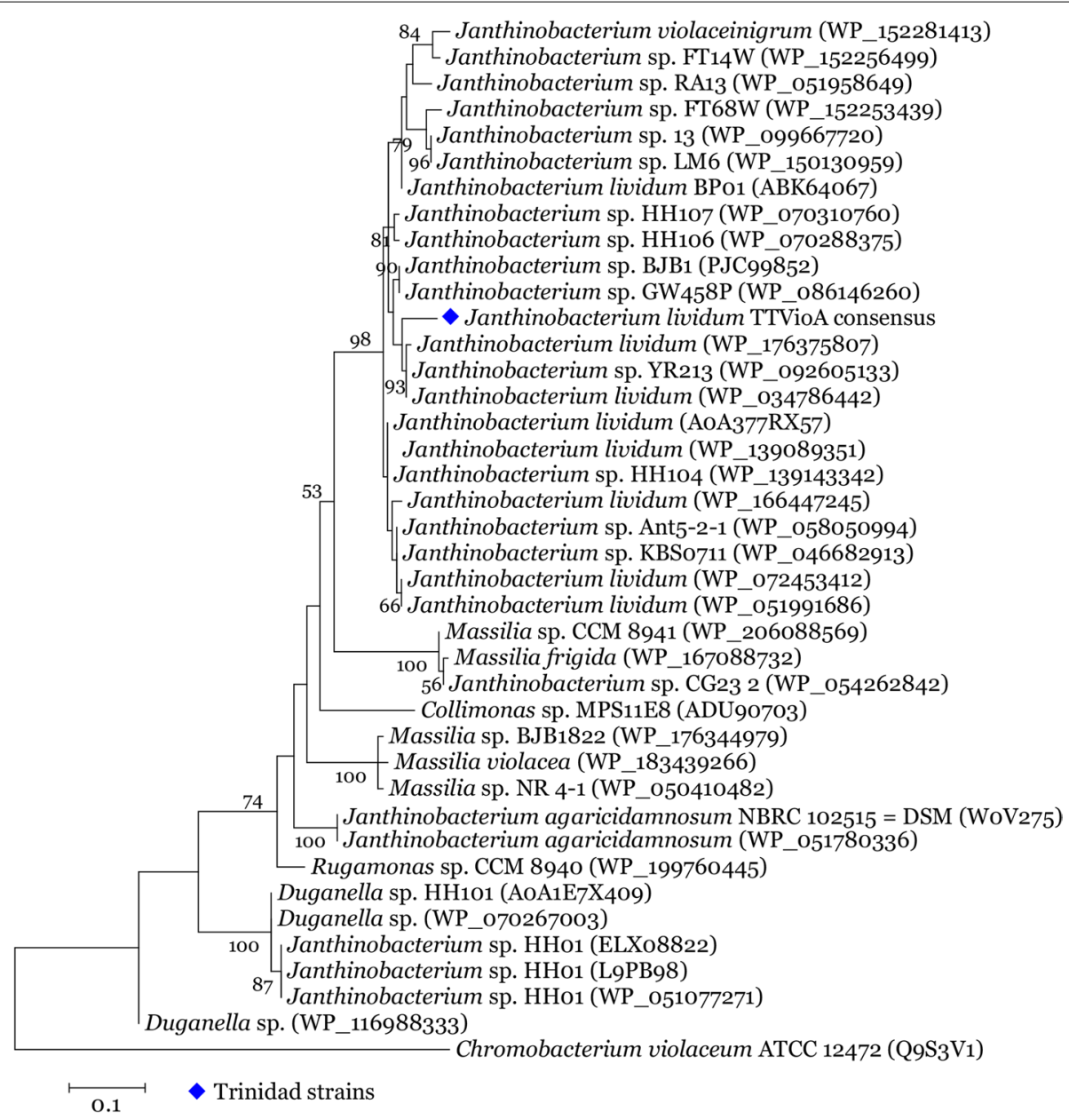

Fig. 5 Molecular phylogenetic analysis by Maximum Likelihood method VioA. The evolutionary history was inferred by using the Maximum Likelihood method based on the JTT matrix-based model. The tree with the highest log likelihood $(-1780.4808)$ is shown. The percentage of trees in which the associated taxa clustered together is shown next to the branches. Initial tree(s) for the heuristic search were obtained by applying the Neighbor-Joining method to a matrix of pairwise distances estimated using a JTT model. A discrete Gamma distribution was used to model evolutionary rate differences among sites $(6$ categories $(+G$, parameter $=1.0012)$ ). The tree is drawn to scale, with branch lengths measured in the number of substitutions per site. The analysis involved 40 amino acid sequences. All positions containing gaps and missing data were eliminated. There were a total of 161 positions in the final dataset. Evolutionary analyses were conducted in MEGAX

co-metabolic mechanism to co-exist with different yeast species in oil-polluted sites.

Interaction networks among members of a specific microbial consortium are significant as it drives complex reactions that can lead to important behavioural shifts [86], which may explain the existence of non-violacein producers that possess the VioABCDE operon. Perhaps the Black Queen hypothesis [87] can be applied to explain (i) the need for motile Trinidad Janthinobacterium strains, and (ii) co-metabolic synergy with yeast which were always recovered as a co-culture in vitro, and which proved to be very difficult to separate into pure, single cultures. This relationship suggests that evolution drives microorganisms to lose essential functions when there is another co-existing species to perform them thereby generating a co-dependency for survival. Such species become "keystone species" where even though they are rare, they are extremely important to the ecosystem [87].

There is a paucity of research related to secretory lipase genes and lipase protein sequences of J. lividum strains. Kumar et al. [34] detected three copies of lipase-encoding genes in the genome sequence of a non-violacein-producing, cold- and high altitude-adapted J. lividum strain ERGS5:01 with demonstrated lipolytic activity in vitro. In this study, synonymous mutations were detected in the EstA/Bp sequence that were unique to the Trinidad strains. While protein function was not affected, these 

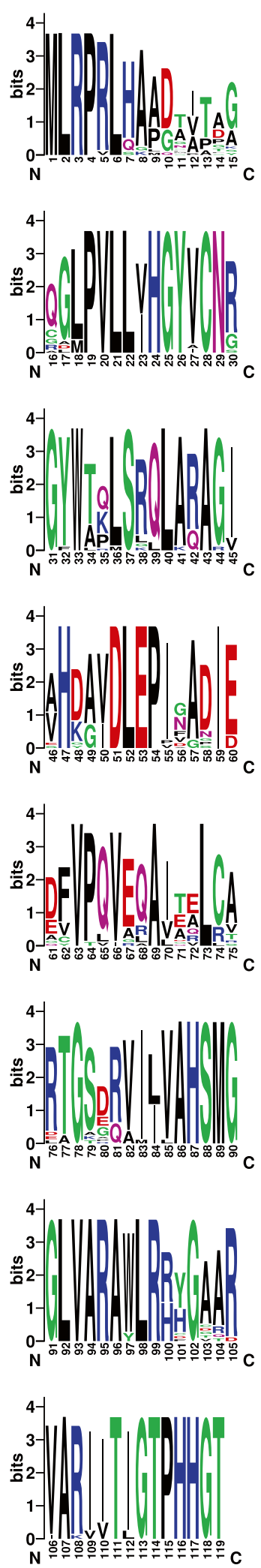

Fig. 6 WebLogo 3 illustration of conserved and variable EstA amino acid positions in the aligned amino acid consensus sequences of the Trinidad strains and two other reference sequences

mutations may alter the structure or function of an mRNA where fitness becomes affected [88]. The findings of Agashe et al. [89] suggest that even single, but highly beneficial synonymous mutations in bacteria, can facilitate rapid evolution and adaptation to their environment. Lebeuf-Taylor et al. [90] reported that for Pseudomonads, synonymous mutations in a given gene can have highly variable fitness effects (deleterious and advantageous), and that these mutations may be more commonplace in nature than previously thought. This study identified synonymous mutations in the VioA and EstA/B genes of Trinidad J. lividum strains. Notwithstanding the specific mechanism(s) by which these synonymous mutations in the VioA and EstA/B genes of Trinidad J. lividum strains their fitness effects, how often and to what degree they contribute to adaptation, should be explored because $J$. lividum is of commercial interest [34].

J. lividum is a strict aerobe and yet, the Trinidad strains have the ability to subsist in hydrocarbon-polluted tropical soils that experience rapid redox fluctuations over short time frames, and which are prone to fluctuations in oxygen levels [91]. But, atypical behaviour by J. lividum strains appears to be related to ecological adaptation [23]. For strict aerobes such as Janthinobacterium in petrogenic environments, the use of oxygen is essential but often inadequate for aerobic degradation due to limited air permeability, and little to no oxygen in waterlogged soil after heavy rainfall [91-98]. Metabolic chemistry fundamentally shifts where water meets sediment. Oxygen concentrations in such ecosystem can rapidly and totally be consumed as a result of a combination of high carbon availability, warm temperatures, abundant rainfall, and clay soils [95]. For bacteria inhabiting tropical soils, a considerable portion of the native community evolved physiological mechanisms to contend with these redox fluctuations [98]. Also, a possible defence for withstanding redox stress as a result of low oxygen, is the deployment of substrate storage mechanisms where bacteria store polyphosphates and volatile fatty acids for delayed use as energy sources similar to studies in aerobic-anaerobic activated sludge [95, 98]. Bacteria can shift their cellular metabolism to adjust to the rate and route of carbon source utilization, pathways of electron flow for oxidation-reduction balance, and their mechanisms of energy production through modulation of gene expression and protein activation in spite of anoxic conditions [91-98]. 


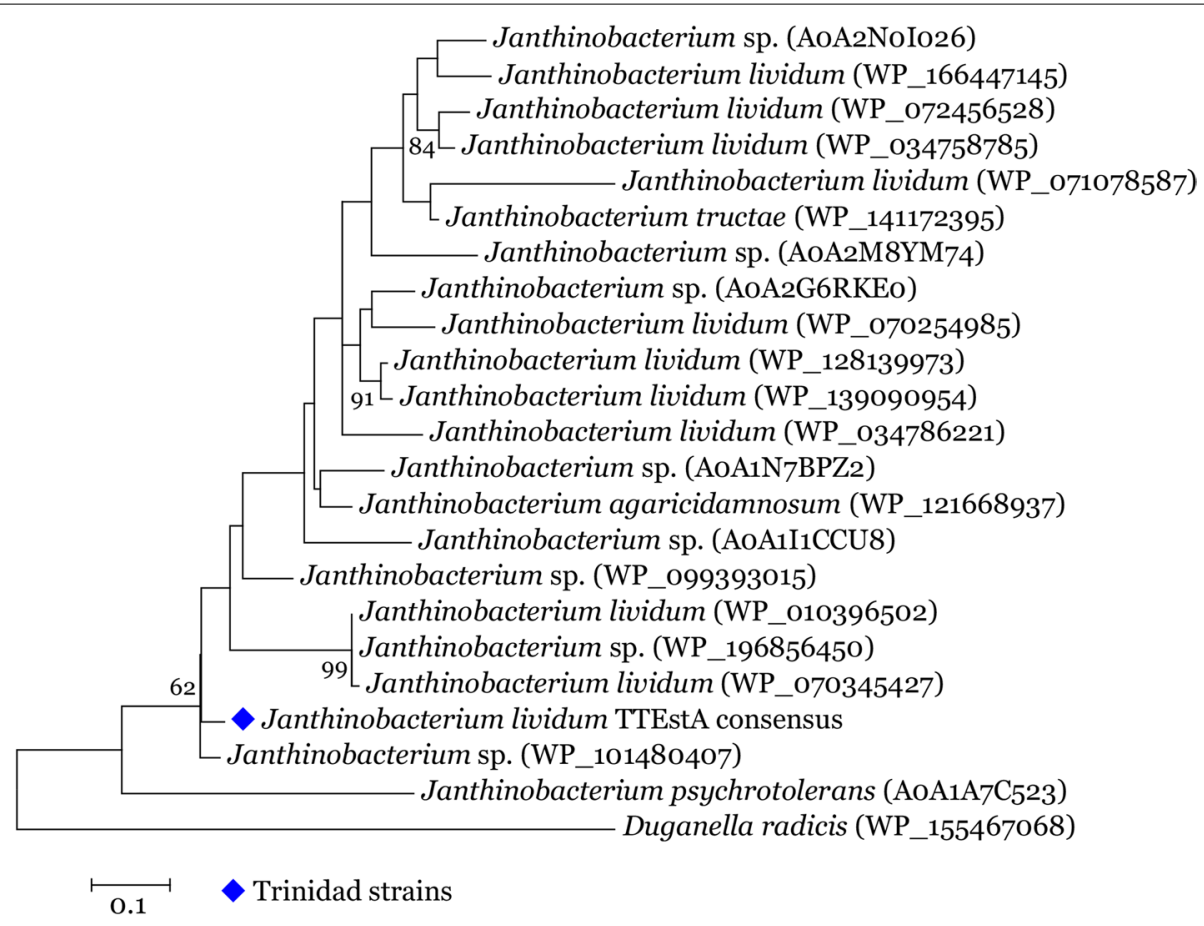

Fig. 7 Molecular phylogenetic analysis by Maximum Likelihood method EstA. The evolutionary history was inferred by using the Maximum Likelihood method based on the JTT matrix-based model. The tree with the highest log likelihood $(-1566.2302)$ is shown. The percentage of trees in which the associated taxa clustered together is shown next to the branches. Initial tree(s) for the heuristic search were obtained by applying the Neighbor-Joining method to a matrix of pairwise distances estimated using a JTT model. A discrete Gamma distribution was used to model evolutionary rate differences among sites $(6$ categories $(+G$, parameter $=0.7842)$ ). The tree is drawn to scale, with branch lengths measured in the number of substitutions per site. The analysis involved 23 amino acid sequences. All positions containing gaps and missing data were eliminated. There were a total of 116 positions in the final dataset. Evolutionary analyses were conducted in MEGAX

\section{Conclusions}

Our findings showed that the primary sequence of VioAp and EstA/Bp were unique to the Trinidad strains and these molecular signatures were reflected in phylogenetic inference. Our results supported chemotaxis, possible elective inactivation of VioA gene expression and secreted lipase activity as survival mechanisms of the Trinidad strains. These complementary mechanisms are closely linked to co-metabolism with other microbes, and may occur as an elective expression of specific genes to accommodate mutualistic survival in polluted soil. Research that examines the bacterial quorum sensing gene cascade, jqsA, qseC, and qseS will improve our understanding of how the unique partnership of $J$. lividum-yeast consortium is co-ordinately regulated. Whole genome and transcriptome sequence analyses of the Trinidad strains would also identify other metabolic pathways that contribute to their survival in polluted environments which can be further explored for bioremediation of contaminated sites and potential discovery of enzymes and proteins of commercial value.

\section{Methods}

\section{Materials}

Crude oil was obtained from CARIRI - Caribbean Industrial (St. Augustine, Trinidad and Tobago). R2A media and nutrient agar were obtained from HiMedia Laboratories LLC (West Chester, PA, USA). Streptomycin, tetracycline, Tris $\mathrm{HCl}$, EDTA, lysozyme, proteinase $\mathrm{K}$, ethidium bromide, olive oil, and Rhodamine 6G solution were obtained from Sigma-Aldrich (St. Louis, MO, USA). Maxwell $^{\circledR} 16$ Cell DNA Purification kits used for DNA extraction, and $\mathrm{GoTaq}^{\circledR}$ Green Master Mix and Nuclease-Free water for PCR were obtained from Promega (Madison, WI, USA). Primers were from Integrated DNA Technologies (Coralville, IA, USA). The Thermal Cycler 2720 to perform PCR was from Thermo Scientific (USA), and the MiniBIS Pro System to view PCR products was a DNR Bio Imaging System (Neve Yamin, Israel).

\section{Isolation of culturable Janthinobacterium sp.}

Janthinobacterium environmental strains, previously reported as efficient hydrocarbon degraders, were used for experimentation in this study. They were selected for sequencing and biochemical analysis due to their 
Table 1 Primer specifications designed to amplify the VioA and EstA/B genes of Janthinobacterium sp.

\begin{tabular}{|c|c|c|c|c|c|c|c|}
\hline Primer name & Primer orientation & $5^{\prime}$ to $3^{\prime}$ Primer sequence & $\begin{array}{l}\text { Start } \\
\text { nucleotide } \\
\text { position }\end{array}$ & Primer length & $\mathrm{Tm}^{\mathrm{a}}$ & $\% \mathrm{GC}$ & $\begin{array}{l}\text { PCR } \\
\text { product/ } \\
\text { bp }\end{array}$ \\
\hline \multirow[t]{2}{*}{ VioA gene-Janthino } & Forward Primer & TCGAGTTCGTCAGCCATTAC & 365 & 20 & 61.7 & 50 & \\
\hline & Reverse Primer & СTTCTTCTTCCGTCCGTTGA & 1264 & 20 & 61.7 & 50 & 900 \\
\hline \multirow[t]{2}{*}{ EstA/B-Janthino } & Forward Primer & GTTGATGCTGCTGCAAGTG & 24 & 19 & 61.9 & 52.6 & \\
\hline & Reverse Primer & TGTCGTGATGCGAATAGATCG & 784 & 21 & 62.1 & 47.6 & 761 \\
\hline
\end{tabular}

${ }^{a}$ Tm PCR annealing temperature

ability to grow on, and utilize crude oil as a unique carbon source. Recovered as a co-cultures with yeast, separation to obtain Janthinobacterium strains was carried out as previously described [50]. The bacterial strains were grown and maintained on R2A media.

\section{Motility}

Janthinobacterium cultures in the log phase of growth were Gram stained and observed under a Brightfield microscope for shape, size and motility [99].

\section{DNA extraction, PCR, sequencing, and identification of microbes}

Total genomic DNA (gDNA) from bacterial cultures was extracted. Bacterial isolates (pure isolates and those in co-culture) were grown on R2A supplemented with $50 \mathrm{mg} / \mathrm{L}$ each of streptomycin and tetracycline in the dark for $16 \mathrm{~h}$ or longer until growth was sufficient for extraction. Plates were flooded with $500-700 \mu \mathrm{L}$ of TE buffer (10 mM Tris $\mathrm{HCl}, 1 \mathrm{mM}$ EDTA, $\mathrm{pH} 8)$. The wash was collected and transferred to a $1.5 \mathrm{~mL}$ centrifuge tube and $100 \mu \mathrm{L}$ of $50 \mathrm{mg} / \mathrm{L}$ each of lysozyme and proteinase $\mathrm{K}$ were added. The samples were incubated at $37^{\circ} \mathrm{C}$ for $2 \mathrm{~h}$ in a water bath with occasional mixing by inversion. Immediately after incubation the entire sample content was transferred to Maxwell ${ }^{\circledR} 16$ Cell DNA Purification kits, and gDNA was extracted according to the manufacturer's protocol. DNA extracts were diluted 1:4, and this served as the working DNA concentration for Polymerase chain reaction (PCR) amplification. The 16S rRNA gene region (expected PCR product size $\sim 1750 \mathrm{bp}$ ) was amplified by PCR with universal primer pair $8 \mathrm{~F}[100]$ and 1492R [101]. PCR reaction conditions consisted of an initial denaturation of $5 \mathrm{~min}$ at $96^{\circ} \mathrm{C}$ followed by 33 cycles of $30 \mathrm{~s}$ of denaturation at $95^{\circ} \mathrm{C}, 30 \mathrm{~s}$ of annealing at $55^{\circ} \mathrm{C}$, 2 min of primer extension at $72^{\circ} \mathrm{C}$, followed by a final extension of $5 \mathrm{~min}$ at $72^{\circ} \mathrm{C}$.

The PCR mixture, $25 \mu \mathrm{L}$ total volume, contained $12.5 \mu \mathrm{L}$ of GoTaq $^{\circledR}$ Green Master Mix, $0.5 \mu \mathrm{L}(10 \mu \mathrm{M})$ of each primer, $6.5 \mu \mathrm{L}$ of Nuclease-Free water, and $5 \mu \mathrm{L}$ of DNA template. All PCR was performed on Thermal Cycler 2720. PCR products were visualized on a $1.5 \%$ agarose gel stained with ethidium bromide, and visualized under MiniBIS Pro System (data not shown). Where amplification failed, samples were processed once again from the first PCR. Samples producing amplicons were sent for purification and sequencing (MCLAB, San Francisco, CA, USA). Identification of sequences was performed using BLASTn (Basic Local Alignment Search Tool) [102] algorithm against the National Centre for Biotechnology Information (NCBI) GenBank database, specifically the NCBI 16S rDNA database.

\section{Vio $A$ and $E s t A / B$ gene detection}

$V i o A$-specific primers were designed to detect the presence of the VioA gene in the Trinidad Janthinobacterium sp. isolates. VioA-encoded amino oxidase catalyzes the first committed step in the biosynthesis of violacein and hence, was selected as a marker for the presence of the violacein operon and a functional VioA gene. Similarly, $E s t A / B \alpha / \beta$ hydrolase enzyme-specific primers were designed to detect the presence of $E s t A / B$ gene encoding secreted extracellular lipase/esterase. The PrimerQuest ${ }^{\mathrm{TM}}$ Tool of IDT DNA Technologies [103] was used to design both sets of primers (Table 1).

The PCR mixture, final volume $25 \mu \mathrm{L}$, for each reaction included $12.5 \mu \mathrm{L}$ of $\mathrm{GoTaq}^{\circledR}{ }^{\circledR}$ Green Master Mix, $0.5 \mu \mathrm{L}(10 \mu \mathrm{M})$ of forward and reverse primers, $6.5 \mu \mathrm{L}$ of Nuclease-Free water, and $5 \mu \mathrm{L}$ of DNA template. PCR reaction conditions included an initial denaturation at $94^{\circ} \mathrm{C}$ for $5 \mathrm{~min}$ followed by 35 cycles of $94^{\circ} \mathrm{C}$ for $1 \mathrm{~min}$, $54^{\circ} \mathrm{C}$ for $1 \mathrm{~min}, 72^{\circ} \mathrm{C}$ for $1 \mathrm{~min}$, ending with a final extension at $72{ }^{\circ} \mathrm{C}$ for $5 \mathrm{~min}$. PCR reactions were carried out on Thermal Cycler 2720, and PCR products were examined on $1.5 \%$ agarose gels stained with ethidium bromide, and visualized under MiniBIS Pro System (data not shown). Samples producing amplicons were sent for purification and sequencing (MCLAB, San Francisco, CA, USA).

\section{Vio $A$ and $E s t A / B$ nucleotide and amino acid sequence analyses}

The nt and aa sequences of VioA and EstA/B of the Trinidad Janthinobacterium strains were analysed to (i) confirm the identity of the gene sequences, and (ii) 


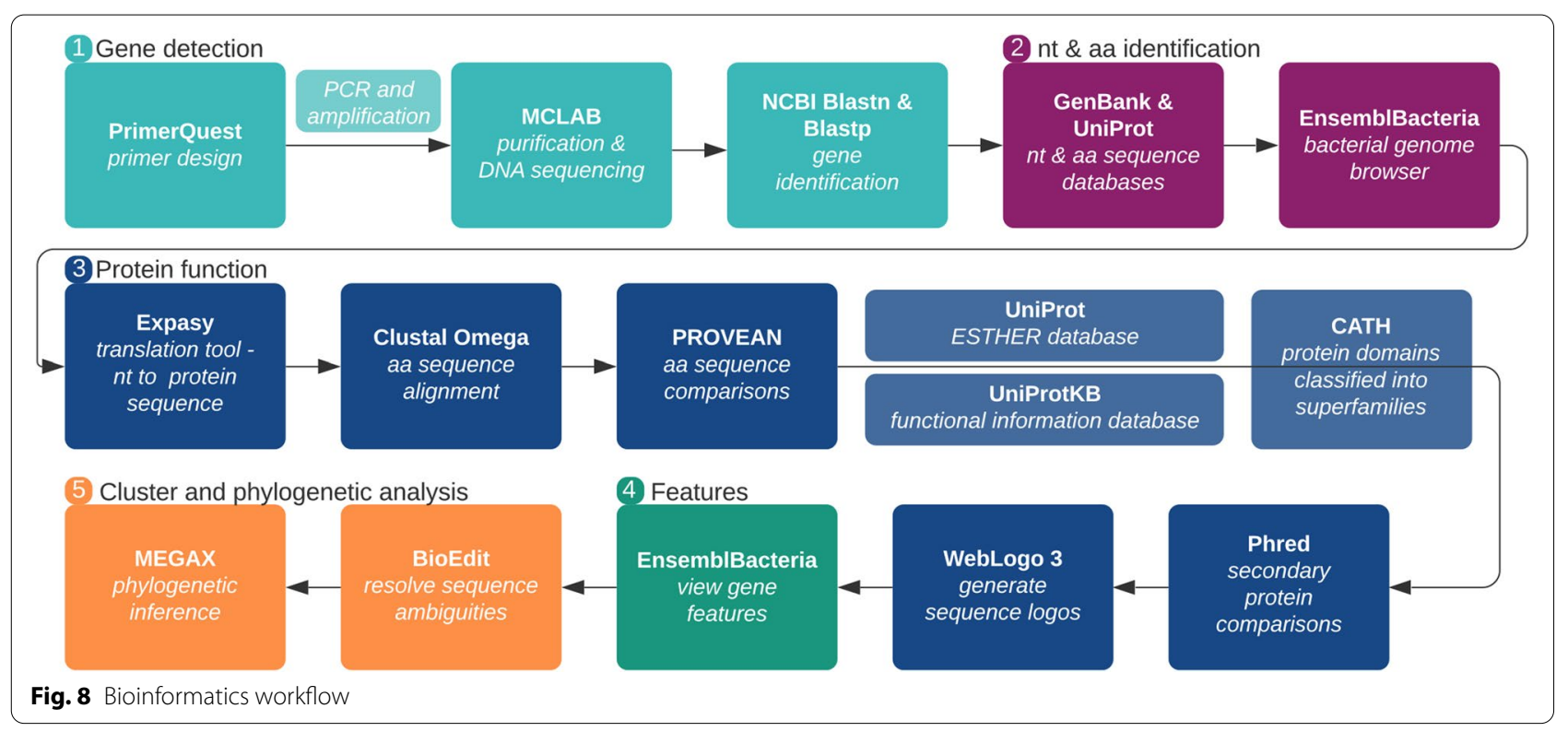

to assess the potential functionality of these genes and their associated gene products. Reference sequences were mined from GenBank [104] and UniProt [105], and an examination of gene regions of whole genomes in EnsemblGenomes [106] and EnsemblBacteria [107] were carried out. Information on violacein-producers and non-producers was recorded for each reference sequence. Translated gene products were predicted using the Expasy server [108]. aa sequence alignments were carried out in Clustal Omega [109]. A comparison of the aa substitutions of Trinidad strains with other strains was done using the PROVEAN server [57, 58], and protein secondary structures were compared on Phred software [110]. Weblogo 3 [111] was used to easily identify those specific aa positions for which there was high aa conservation and high aa variability. VioA gene features e.g. operon arrangement and domain synteny were examined in EnsemblBacteria [107]. Because of only minor differences in secondary structure prediction detected in Phred, PDB 3D model 6g2p ( $C$. violaceum strain ATCC 12472) was used to assess the outcome of amino acid changes at critical sites in the protein model for L-tryptophan oxidase in terms of the FAD-cofactor binding sites, tryptophan substrate binding sites, and overall binding sites for this enzyme. This data was also compared to mutagenesis studies carried out for C. violaceum strain ATCC 12472 (UniProt Q953V1).

\section{Cluster analyses and phylogenetic inference}

$16 \mathrm{~S}$ rRNA, VioA and EstA/B aa sequences were analysed relative to sequences of other Janthinobacterium sequences specifically and more broadly, relative to other members of the Oxalobacteraceae family of betaproteobacteria. DNA sequences were manually edited using BioEdit software, version 7.1.9 [112] to resolve aa sequence ambiguities. Phylogenetic inference was carried out using the best fit model in MEGAX [113] using the ML algorithm with 1000 bootstrapped replications. The $50 \%$ consensus trees (bs $>50 \%$ ) are presented. Reference sequence data are presented in Supplemental materials as Table S1 to Table S3. A summary of all bioinformatics analyses is presented in Fig. 8.

\section{Supplementary Information}

The online version contains supplementary material available at https://doi. org/10.1186/s12866-021-02346-4.

\section{Additional file 1.}

Additional file 2: Table S1. List of reference sequences and GenBank accession numbers used in phylogenetic analyses of 16S rRNA gene region. Table S2. List of reference protein sequences and GenBank and UniProt accession numbers used in VioA protein tree. Table S3. List of reference protein sequences, GenBank and UniProt accession numbers used in construction of the EstA/B protein tree.

\section{Acknowledgements}

The authors wish to thank Mr. Vijai Ramdhan, Mr. Stephen Narine, Mr. Brent Daniel and Dr. Adesh Ramsubhag for field assistance. 


\section{Authors' contributions}

ACR and SNR prepared the manuscript and performed analysis of the data SNR executed the conceptualization and design of experiments. All authors read and approved the final manuscript.

\section{Funding}

This research was supported by The University of the West Indies Campus Research and Publications Grant (CRP.5.OCT18.77) for ACR, and a Staff Benefit Grant to SNR.

\section{Availability of data and materials}

All data generated or analysed during this study are included in this published article and its supplementary information files.

\section{Declarations}

\section{Ethics approval and consent to participate}

This work required no ethics approval as human and animal subjects were not used.

\section{Consent for publication}

This work required no consent for publication.

\section{Competing interests}

The authors declare that they have no competing interests.

Received: 2 July 2021 Accepted: 6 October 2021

Published online: 20 October 2021

\section{References}

1. Hamme JDV, Singh A, Ward OP. Recent advances in petroleum microbiology. Microbiol Mol Biol Rev. 2003;67(4):503-49. https://doi.org/10. 1128/MMBR.67.4.503-549.2003.

2. Ali N, Dashti N, Khanafer M, Al-Awadhi H, Radwan S. Bioremediation of soils saturated with spilled crude oil. Sci Rep. 2020;10(1):1116. https:// doi.org/10.1038/s41598-019-57224-x.

3. Gibson DT, Parales RE. Aromatic hydrocarbon dioxygenases in environmental biotechnology. Curr Opin Biotechnol. 2000;11(3):236-43. https://doi.org/10.1016/S0958-1669(00)00090-2.

4. Mahjoubi M, Jaouani A, Guesmi A, Ben Amor S, Jouini A, Cherif H, et al. Hydrocarbonoclastic bacteria isolated from petroleum contaminated sites in Tunisia: isolation, identification and characterization of the biotechnological potential. New Biotechnol. 2013;30(6):723-33. https:// doi.org/10.1016/j.nbt.2013.03.004.

5. Sikkema J, de Bont JA, Poolman B. Mechanisms of membrane toxicity of hydrocarbons. Microbiol Rev. 1995;59(2):201-22. https://doi.org/10. 1128/mr.59.2.201-222.1995

6. Hua F, Wang HQ. Uptake and trans-membrane transport of petroleum hydrocarbons by microorganisms. Biotechnol Biotechnol Equip. 2014;28(2):165-75. https://doi.org/10.1080/13102818.2014.906136.

7. Holmquist M. Alpha beta-hydrolase fold enzymes structures, functions and mechanisms. Curr Protein Pept Sci. 2000;1(2):209-35. https://doi. org/10.2174/1389203003381405.

8. Pérez-Pantoja D, Donoso R, Junca H, González B, Pieper DH. Phylogenomics of aerobic bacterial degradation of aromatics. In: Timmis $\mathrm{KN}$, editor. Handbook of hydrocarbon and lipid microbiology. Berlin, Heidelberg: Springer Berlin Heidelberg; 2010. p. 1355-97.

9. Rojo F. Degradation of alkanes by bacteria. Environ Microbiol. 2009;11(10):2477-90. https://doi.org/10.1111/j.1462-2920.2009.01948.x.

10. Wang W, Shao Z. Enzymes and genes involved in aerobic alkane degradation. Front Microbiol. 2013;4:116. https://doi.org/10.3389/fmicb.2013. 00116.

11. Birolli WG, Lima RN, Porto ALM. Applications of marine-derived microorganisms and their enzymes in biocatalysis and biotransformation, the underexplored potentials. Front Microbiol. 2019;10:1453. https://doi. org/10.3389/fmicb.2019.01453.
12. Pandey A, Benjamin S, Soccol CR, Nigam P, Krieger N, Soccol VT. The realm of microbial lipases in biotechnology. Biotechnol Appl Biochem. 1999;29(2):119-31. https://doi.org/10.1111/j.1470-8744.1999.tb00541.x.

13. Baldani J, Rouws L, Cruz L, Olivares F, Schmid M, Hartmann A. The family Oxalobacteraceae. In: Rosenberg E, DeLong EF, Lory S, Stackebrandt E, Thompson F, editors. The prokaryotes: alphaproteobacteria and betaproteobacteria. Berlin, Heidelberg: Springer; 2014. p. 919-74.

14. Kämpfer P, Falsen E, Busse H-J. Reclassification of Pseudomonas mephitica Claydon and Hammer 1939 as a later heterotypic synonym of Janthinobacterium lividum (Eisenberg 1891) De Ley et al. 1978. Int J Syst Evol Microbiol. 2008;58(1):136-8. https://doi.org/10.1099/ijs.0.65450-0.

15. Ambrožič Avguštin J, Žgur Bertok D, Kostanjšek R, Avguštin G. Isolation and characterization of a novel violacein-like pigment producing psychrotrophic bacterial species Janthinobacterium svalbardensis sp. nov. Antonie Van Leeuwenhoek. 2013;103(4):763-9. https://doi.org/10.1007/ s10482-012-9858-0.

16. Lincoln SP, Fermor TR, Tindall BJ. Janthinobacterium agaricidamnosum sp. nov., a soft rot pathogen of Agaricus bisporus. Int J Syst Evol Microbiol. 1999;49(4):1577-89. https://doi.org/10.1099/00207713-49-4-1577.

17. Lu H, Deng T, Cai Z, Liu F, Yang X, Wang Y, et al. Janthinobacterium violaceinigrum sp. nov., Janthinobacterium aquaticum sp. nov. and Janthinobacterium rivuli sp. nov., isolated from a subtropical stream in China. Int J Syst Evol Microbiol. 2020;70(4):2719-25. https://doi.org/10. 1099/ijsem.0.004097.

18. Suman R, Sharma P, Gupta S, Sourirajan A, Dev K. A novel psychrophilic Janthinobacterium lividum MMPP4 isolated from Manimahesh Lake of Chamba district of Himachal Pradesh, India. J Biochem Technol. 2015;6(1):846-51.

19. Asencio G, Lavin P, Alegría K, Domínguez M, Bello H, González-Rocha G, et al. Antibacterial activity of the Antarctic bacterium Janthinobacterium sp.: SMN 33.6 against multi-resistant Gram-negative bacteria. Electron J Biotechnol. 2014;17(1):1-5.

20. Shoemaker WR, Muscarella ME, Lennon JT. Genome sequence of the soil bacterium Janthinobacterium sp. KBS0711. Genome Announc. 2015;3(3):e00689-15. https://doi.org/10.1128/genomeA.00689-15.

21. Wu X, Deutschbauer AM, Kazakov AE, Wetmore KM, Cwick BA, Walker RM, et al. Draft genome sequences of two Janthinobacterium lividum strains, isolated from pristine groundwater collected from the Oak Ridge Field Research Center. Genome Announc. 2017;5(26):e00582-17. https://doi.org/10.1128/genomeA.00582-17.

22. McTaggart TL, Shapiro N, Woyke T, Chistoserdova L. Draft genome of Janthinobacterium sp. RA13 isolated from Lake Washington sediment. Genome Announc. 2015;3(1):e01588-14. https://doi.org/10.1128/ genomeA.01588-14.

23. Haack FS, Poehlein A, Kröger C, Voigt CA, Piepenbring M, Bode HB, et al. Molecular keys to the Janthinobacterium and Duganella spp. interaction with the plant pathogen Fusarium graminearum. Front Microbiol 2016;7:1668. https://doi.org/10.3389/fmicb.2016.01668.

24. Brucker RM, Harris RN, Schwantes CR, Gallaher TN, Flaherty DC, Lam BA, et al. Amphibian chemical defense: antifungal metabolites of the microsymbiont Janthinobacterium lividum on the Salamander Plethodon cinereus. J Chem Ecol. 2008;34(11):1422-9. https://doi.org/ 10.1007/s10886-008-9555-7.

25. Harris RN, Brucker RM, Walke JB, Becker MH, Schwantes CR, Flaherty $D C$, et al. Skin microbes on frogs prevent morbidity and mortality caused by a lethal skin fungus. ISME J. 2009;3(7):818-24. https://doi. org/10.1038/ismej.2009.27.

26. Oh WT, Giri SS, Yun S, Kim HJ, Kim SG, Kim SW, et al. Janthinobacterium lividum as an emerging pathogenic bacterium affecting rainbow trout (Oncorhynchus mykiss) fisheries in Korea. Pathogens. 2019;8(3):146. https://doi.org/10.3390/pathogens8030146.

27. Andrighetti-Fröhner C, Antonio R, Creczynski-Pasa T, Barardi C, Simões C. Cytotoxicity and potential antiviral evaluation of violacein produced by Chromobacterium violaceum. Mem Inst Oswaldo Cruz. 2003;98(6):843-8. https://doi.org/10.1590/S0074-027620030006000 23.

28. Bromberg N, Dreyfuss JL, Regatieri CV, Palladino MV, Durán N, Nader $\mathrm{HB}$, et al. Growth inhibition and pro-apoptotic activity of violacein in Ehrlich ascites tumor. Chem Biol Interact. 2010;186(1):43-52. https:// doi.org/10.1016/j.cbi.2010.04.016. 
29. August P, Grossman T, Minor C, Draper M, MacNeil I, Pemberton $J$, et al. Sequence analysis and functional characterization of the violacein biosynthetic pathway from Chromobacterium violaceum. J Microbiol Biotechnol. 2000;2(4):513-9.

30. Antônio RV, Creczynski-Pasa TB. Genetic analysis of violacein biosynthesis by Chromobacterium violaceum. Genet Mol Res. 2004;3(1):85-91.

31. Morohoshi T, Fukamachi K, Kato M, Kato N, Ikeda T. Regulation of the violacein biosynthetic gene cluster by acylhomoserine lactonemediated quorum sensing in Chromobacterium violaceum ATCC 12472. Biosci Biotechnol Biochem. 2010;74(10):2116-9. https://doi.org/10. 1271/bbb.100385.

32. Stauff DL, Bassler BL. Quorum sensing in Chromobacterium violaceum: DNA recognition and gene regulation by the CviR receptor. J Bacteriol. 2011;193(15):3871-8. https://doi.org/10.1128/JB.05125-11.

33. Hornung C, Poehlein A, Haack FS, Schmidt M, Dierking K, Pohlen A, et al. The Janthinobacterium sp. HHO1 genome encodes a homologue of the $V$. cholerae CqsA and L. pneumophila LqsA autoinducer synthases. PLoS One. 2013;8(2):e55045. https://doi.org/10.1371/journal.pone.0055045.

34. Kumar R, Acharya V, Singh D, Kumar S. Strategies for high-altitude adaptation revealed from high-quality draft genome of non-violacein producing Janthinobacterium lividum ERGS5:01. Stand Genomic Sci. 2018;13(1):11. https://doi.org/10.1186/s40793-018-0313-3.

35. Wada N, Sakamoto T, Matsugo S. Multiple roles of photosynthetic and sunscreen pigments in Cyanobacteria focusing on the oxidative stress. Metabolites. 2013;3(2):463-83. https://doi.org/10.3390/metabo3020 463.

36. Suresh M, Renugadevi B, Brammavidhya S, Iyapparaj P, Anantharaman P. Antibacterial activity of red pigment produced by Halolactibacillus alkaliphilus MSRD1-an isolate from seaweed. Appl Biochem Biotechnol. 2015;176(1):185-95. https://doi.org/10.1007/s12010-015-1566-6.

37. van Duin D, Casadevall A, Nosanchuk JD. Melanization of Cryptococcus neoformans and Histoplasma capsulatum reduces their susceptibilities to amphotericin B and caspofungin. Antimicrob Agents Chemother. 2002;46(11):3394-400. https://doi.org/10.1128/AAC.46.11.3394-3400. 2002.

38. Pantanella F, Berlutti F, Passariello C, Sarli S, Morea C, Schippa S. Violacein and biofilm production in Janthinobacterium lividum. J Appl Microbiol. 2007;102(4):992-9. https://doi.org/10.1111/j.1365-2672.2006.03155.X.

39. Lee LP, Karbul HM, Citartan M, Gopinath SCB, Lakshmipriya T, Tang T-H. Lipase-secreting Bacillus species in an oil-contaminated habitat: promising strains to alleviate oil pollution. Biomed Res Int. 2015;2015:820575. https://doi.org/10.1155/2015/820575.

40. Hasan F, Shah AA, Hameed A. Industrial applications of microbial lipases. Enzym Microb Technol. 2006;39(2):235-51. https://doi.org/10. 1016/j.enzmictec.2005.10.016.

41. Casas-Godoy L, Duquesne S, Bordes F, Sandoval G, Marty A. Lipases: an overview. In: Sandoval G, editor. Lipases and phospholipases: methods and protocols. Totowa: Humana Press; 2012. p. 3-30.

42. Treichel H, de Oliveira D, Mazutti MA, Di Luccio M, Oliveira JV. A review on microbial lipases production. Food Bioprocess Technol. 2010;3(2):182-96. https://doi.org/10.1007/s1 1947-009-0202-2.

43. Saxena RK, Sheoran A, Giri B, Davidson WS. Purification strategies for microbial lipases. J Microbiol Methods. 2003;52(1):1-18. https://doi.org/ 10.1016/S0167-7012(02)00161-6.

44. Nagarajan S. New tools for exploring "old friends-microbial lipases". Appl Biochem Biotechnol. 2012;168(5):1163-96. https://doi.org/10.1007/ s12010-012-9849-7.

45. Liu P-W, Chang TC, Whang L-M, Kao C-H, Pan P-T, Cheng S-S. Bioremediation of petroleum hydrocarbon contaminated soil: effects of strategies and microbial community shift. Int Biodeterior Biodegradation. 2011;65(8):1119-27. https://doi.org/10.1016/j.ibiod.2011.09.002.

46. Park C, Park W. Survival and energy producing strategies of alkane degraders under extreme conditions and their biotechnological potential. Front Microbiol. 2018;9:1081. https://doi.org/10.3389/fmicb.2018. 01081.

47. Nzila A. Current status of the degradation of aliphatic and aromatic petroleum hydrocarbons by thermophilic microbes and future perspectives. Int J Environ Res Public Health. 2018;15(12):2782. https://doi. org/10.3390/ijerph15122782.
48. Atalah J, Cáceres-Moreno P, Espina G, Blamey JM. Thermophiles and the applications of their enzymes as new biocatalysts. Bioresour Technol. 2019;280:478-88. https://doi.org/10.1016/j.biortech.2019.02.008.

49. Yusoff DF, Raja Abd Rahman RNZ, Masomian M, MSM A, Leow TC. Newly isolated alkane hydroxylase and lipase producing Geobacillus and Anoxybacillus species involved in crude oil degradation. Catalysts. 2020;10(8):851. https://doi.org/10.3390/catal10080851.

50. Ramdass AC, Rampersad SN. Diversity and oil degradation potential of culturable microbes isolated from chronically contaminated soils in Trinidad. Microorganisms. 2021;9(6):1167. https://doi.org/10.3390/micro organisms9061167.

51. Schloss PD, Handelsman J. Introducing DOTUR, a computer program for defining operational taxonomic units and estimating species richness. Appl Environ Microbiol. 2005;71(3):1501-6. https://doi.org/10. 1128/AEM.71.3.1501-1506.2005.

52. NCBI GenBank JF266634. https://www.ncbi.nIm.nih.gov/nuccore/JF266 634. Accessed 23 June 2021.

53. NCBI GenPept: UniProtKB/Swiss-Prot Q9S3V1.2. https://www.ncbi.nlm. nih.gov/protein/Q9S3V1. Accessed 23 June 2021.

54. Füller JJ, Röpke R, Krausze J, Rennhack KE, Daniel NP, Blankenfeldt $W$, et al. Biosynthesis of violacein, structure and function of L-tryptophan oxidase VioA from Chromobacterium violaceum. J Biol Chem. 2016;291(38):20068-84. https://doi.org/10.1074/jbc.M1 16.741561.

55. Hoshino T. Violacein and related tryptophan metabolites produced by Chromobacterium violaceum: biosynthetic mechanism and pathway for construction of violacein core. Appl Microbiol Biotechnol. 2011;91(6):1463-75. https://doi.org/10.1007/s00253-011-3468-z.

56. Sillitoe I BN, Dawson N, Waman VP, Ashford P, Scholes HM, Pang CSM, Woodridge L, Rauer C, Sen N, Abbasian M, Le Cornu S, Lam SD, Berka K, Varekova IH, Svobodova R, Lees J, Orengo CA. CATH: increased structural coverage of functional space. 2021. http://www.cathdb.info/versi on/v4_3_0/superfamily/3.40.50.1820/funfam/182/alignment. Accessed 3 June 2021.

57. Choi Y, Chan AP. PROVEAN web server: a tool to predict the functional effect of amino acid substitutions and indels. Bioinformatics. 2015;31(16):2745-7. https://doi.org/10.1093/bioinformatics/btv195.

58. PROVEAN. http://provean.jcvi.org/index.php. Accessed 23 June 2021.

59. UniProtKB - Q9S3V1 (VIOA_CHRVO). https://www.uniprot.org/uniprot/ Q9S3V1. Accessed 24 June 2021.

60. ESTHER database of the Alpha/Beta-hydrolase fold superfamily of proteins. https://www.uniprot.org/database/DB-0193. Accessed 3 June 2021.

61. Davis JJ, Wattam AR, Aziz RK, Brettin T, Butler R, Butler RM, et al. The PATRIC Bioinformatics Resource Center: expanding data and analysis capabilities. Nucleic Acids Res. 2020;48(D1):D606-12.

62. Valdes N, Soto P, Cottet L, Alarcon P, Gonzalez A, Castillo A, et al. Draft genome sequence of Janthinobacterium lividum strain MTR reveals its mechanism of capnophilic behavior. Stand Genomic Sci. 2015;10(1):110. https://doi.org/10.1186/s40793-015-0104-z.

63. Schloss PD, Allen HK, Klimowicz AK, Mlot C, Gross JA, Savengsuksa S, et al. Psychrotrophic strain of Janthinobacterium lividum from a cold Alaskan soil produces prodigiosin. DNA Cell Biol. 2010;29(9):533-41. https://doi.org/10.1089/dna.2010.1020.

64. Baricz A, Teban A, Chiriac CM, Szekeres E, Farkas A, Nica M, et al. Investigating the potential use of an Antarctic variant of Janthinobacterium lividum for tackling antimicrobial resistance in a One Health approach. Sci Rep. 2018;8(1):1-12. https://doi.org/10.1038/s41598-018-33691-6.

65. Lyakhovchenko NS, Abashina TN, Polivtseva VN, Senchenkov VY, Pribylov DA, Chepurina AA, et al. A blue-purple pigment-producing bacterium isolated from the Vezelka River in the city of Belgorod. Microorganisms. 2021;9(1):102. https://doi.org/10.3390/microorganisms9 010102.

66. Jaspers E, Overmann J. Ecological significance of microdiversity: identical 16S rRNA gene sequences can be found in bacteria with highly divergent genomes and ecophysiologies. Appl Environ Microbiol. 2004;70(8):4831-9. https://doi.org/10.1128/AEM.70.8.4831-4839.2004.

67. Garrity GM, Bell JA, Lilburn T. Family II. Oxalobacteraceae fam. nov. In: Brenner DJ, Krieg NR, Staley JT, Garrity GM, editors. Bergey's manual of systematic bacteriology. New York: Springer; 2005. p. 623. 
68. Xie L, Wu X-L. Bacterial motility patterns reveal importance of exploitation over exploration in marine microhabitats. Part I: theory. Biophys J. 2014;107(7):1712-20. https://doi.org/10.1016/j.bpj.2014.07.058.

69. Dechesne A, Smets BF. Pseudomonad swarming motility is restricted to a narrow range of high matric water potentials. Appl Environ Microbiol. 2012;78(8):2936-40. https://doi.org/10.1128/AEM.06833-11.

70. Dechesne A, Wang G, Gülez G, Or D, Smets BF. Hydration-controlled bacterial motility and dispersal on surfaces. Proc Natl Acad Sci U S A 2010;107(32):14369. https://doi.org/10.1073/pnas.1008392107.

71. Kohlmeier S, Smits THM, Ford RM, Keel C, Harms H, Wick LY. Taking the fungal highway: mobilization of pollutant-degrading bacteria by fungi. Environ Sci Technol. 2005;39(12):4640-6. https://doi.org/10.1021/es047 979z.

72. Wick LY, Remer R, Würz B, Reichenbach J, Braun S, Schäfer F, et al. Effect of fungal hyphae on the access of bacteria to phenanthrene in soil. Environ Sci Technol. 2007;41(2):500-5. https://doi.org/10.1021/es061 407s.

73. Warmink JA, van Elsas JD. Migratory response of soil bacteria to Lyophyllum sp. strain karsten in soil microcosms. Appl Environ Microbiol. 2009;75(9):2820-30. https://doi.org/10.1128/AEM.02110-08.

74. Warmink JA, Nazir R, Corten B, van Elsas JD. Hitchhikers on the fungal highway: the helper effect for bacterial migration via fungal hyphae. Soil Biol Biochem. 2011;43(4):760-5. https://doi.org/10.1016/j.soilbio. 2010.12.009.

75. Furuno S, Päzolt K, Rabe C, Neu TR, Harms H, Wick LY. Fungal mycelia allow chemotactic dispersal of polycyclic aromatic hydrocarbondegrading bacteria in water-unsaturated systems. Environ Microbiol. 2010;12(6):1391-8. https://doi.org/10.1111/j.1462-2920.2009.02022.x.

76. Wösten HAB, van Wetter M-A, Lugones LG, van der Mei HC, Busscher HJ, Wessels JGH. How a fungus escapes the water to grow into the air. Curr Biol. 1999;9(2):85-8. https://doi.org/10.1016/S0960-9822(99)80019-0.

77. Pion M, Bshary R, Bindschedler S, Filippidou S, Wick LY, Job D, et al. Gains of bacterial flagellar motility in a fungal world. Appl Environ Microbiol. 2013;79(22):6862-7. https://doi.org/10.1128/AEM.01393-13.

78. Banitz T, Fetzer I, Johst K, Wick LY, Harms H, Frank K. Assessing biodegradation benefits from dispersal networks. Ecol Model. 2011;222(14):2552-60. https://doi.org/10.1016/j.ecolmodel.2010.07.005

79. Friedrich I, Hollensteiner J, Schneider D, Poehlein A, Hertel R, Daniel R. First complete genome sequences of Janthinobacterium lividum EIF1 and EIF2 and their comparative genome analysis. Genome Biol Evol. 2020;12(10):1782-8.

80. Choi SY, Kim S, Lyuck S, Kim SB, Mitchell RJ. High-level production of violacein by the newly isolated Duganella violaceinigra str. NI28 and its impact on Staphylococcus aureus. Sci Rep. 2015;5(1):1-12.

81. Natalia C, Mayra-Alexandra C, Vanessa C, Luis-Daniel P. Influence of environmental factors on the production of violacein synthesized by Janthinobacterium lividum. Int J Eng Sci. 2017;6(01):76-83. https://doi. org/10.9790/1813-0601037683.

82. Bervoets I, Charlier D. Diversity, versatility and complexity of bacterial gene regulation mechanisms: opportunities and drawbacks for applications in synthetic biology. FEMS Microbiol Rev. 2019;43(3):304-39. https://doi.org/10.1093/femsre/fuz001.

83. Juhas M, Eberl L, Tümmler B. Quorum sensing: the power of cooperation in the world of Pseudomonas. Environ Microbiol. 2005;7(4):459-71. https://doi.org/10.1111/j.1462-2920.2005.00769.x.

84. Suntharalingam P, Cvitkovitch DG. Quorum sensing in streptococcal biofilm formation. Trends Microbiol. 2005;13(1):3-6. https://doi.org/10. 1016/j.tim.2004.11.009.

85. Cornforth DM, Foster KR. Competition sensing: the social side of bacterial stress responses. Nat Rev Microbiol. 2013;11(4):285-93. https://doi. org/10.1038/nrmicro2977

86. Deveau A, Bonito G, Uehling J, Paoletti M, Becker M, Bindschedler S, et al. Bacterial-fungal interactions: ecology, mechanisms and challenges. FEMS Microbiol Rev. 2018;42(3):335-52. https://doi.org/10.1093/ femsre/fuy008.

87. Morris JJ, Lenski RE, Zinser ER. The black queen hypothesis: evolution of dependencies through adaptive gene loss. mBio. 2012;3(2):e00036-12. https://doi.org/10.1128/mBio.00036-12.

88. Kristofich J, Morgenthaler AB, Kinney WR, Ebmeier CC, Snyder DJ, Old WM, et al. Synonymous mutations make dramatic contributions to fitness when growth is limited by a weak-link enzyme. PLoS Genet. 2018;14(8):e1007615. https://doi.org/10.1371/journal.pgen.1007615.

89. Agashe D, Sane M, Phalnikar K, Diwan GD, Habibullah A, MartinezGomez NC, et al. Large-effect beneficial synonymous mutations mediate rapid and parallel adaptation in a bacterium. Mol Biol Evol. 2016;33(6):1542-53. https://doi.org/10.1093/molbev/msw035.

90. Lebeuf-Taylor E, McCloskey N, Bailey SF, Hinz A, Kassen R. The distribution of fitness effects among synonymous mutations in a gene under directional selection. eLife. 2019;8:e45952. https://doi.org/10.7554/eLife 45952.

91. Fierer N. Embracing the unknown: disentangling the complexities of the soil microbiome. Nat Rev Microbiol. 2017;15(10):579-90. https://doi. org/10.1038/nrmicro.2017.87.

92. Nakano MM, Zuber P. Anaerobic growth of a "strict aerobe" (Bacillus subtilis). Annu Rev Microbiol. 1998;52(1):165-90. https://doi.org/10. 1146/annurev.micro.52.1.165.

93. van Keulen G, Alderson J, White J, Sawers RG. The obligate aerobic actinomycete Streptomyces coelicolor A3(2) survives extended periods of anaerobic stress. Environ Microbiol. 2007;9(12):3143-9. https://doi. org/10.1111/j.1462-2920.2007.01433.x.

94. Brzeszcz J, Kaszycki P. Aerobic bacteria degrading both n-alkanes and aromatic hydrocarbons: an undervalued strategy for metabolic diversity and flexibility. Biodegradation. 2018;29(4):359-407. https://doi.org/10. 1007/s10532-018-9837-x.

95. Pett-Ridge J, Firestone MK. Redox fluctuation structures microbial communities in a wet tropical soil. Appl Environ Microbiol. 2005;71(11):6998-7007. https://doi.org/10.1128/AEM.71.11.6998-7007. 2005.

96. Carucci A, Lindrea K, Majone M, Ramadori R. Different mechanisms for the anaerobic storage of organic substrates and their effect on enhanced biological phosphate removal (EBPR). Water Sci Technol. 1999;39(6):21-8. https://doi.org/10.1016/S0273-1223(99)00119-5.

97. Schuler AJ, Jenkins D, Ronen P. Microbial storage products, biomass density, and settling properties of enhanced biological phosphorus removal activated sludge. Water Sci Technol. 2001;43(1):173-80. https:// doi.org/10.2166/wst.2001.0042.

98. Ciemniecki JA, Newman DK, Margolin W. The potential for redox-active metabolites to enhance or unlock anaerobic survival metabolisms in aerobes. J Bacteriol. 2020;202(11):e00797-19. https://doi.org/10.1128/ JB.00797-19.

99. Smith AC, Hussey MA. Gram stain protocols. 2005. https://www.asmsc ience.org/content/education/protocol/protocol.2886?crawler=true. Accessed 23 June 2021.

100. Turner S, Pryer KM, Miao VP, Palmer JD. Investigating deep phylogenetic relationships among cyanobacteria and plastids by small subunit rRNA sequence analysis 1. J Eukaryot Microbiol. 1999;46(4):327-38. https:// doi.org/10.1111/j.1550-7408.1999.tb04612.x

101. Lane D. 16S/23S rRNA sequencing. In: Stackebrandt E, Goodfellow M, editors. Nucleic acid techniques in bacterial systematics. Chichester: Wiley; 1991. p. 115-75.

102. Altschul SF, Gish W, Miller W, Myers EW, Lipman DJ. Basic local alignment search tool. J Mol Biol. 1990;215(3):403-10. https://doi.org/10. 1016/S0022-2836(05)80360-2.

103. PrimerQuest ${ }^{\mathrm{TM}}$ Tool. https://www.idtdna.com/pages/tools/primerquest. Accessed 23 June 2021.

104. GenBank. https://www.ncbi.nlm.nih.gov/genbank/. Accessed 23 June 2021.

105. UniProt. https://www.uniprot.org/. Accessed 23 June 2021.

106. e!EnsembleGenomes https://ensemblgenomes.org/. Accessed 23 June 2021.

107. e!EnsemblBacteria https://bacteria.ensembl.org/index.html. Accessed 23 June 2021

108. Expasy. https://web.expasy.org/translate/. Accessed 23 June 2021.

109. Clustal Omega. https://www.ebi.ac.uk/Tools/msa/clustalo/. Accessed 23 June 2021.

110. Ewing B, Hillier L, Wendl MC, Green P. Base-calling of automated sequencer traces using Phred. I. accuracyassessment. Genome Res. 1998;8(3):175-85. https://doi.org/10.1101/gr.8.3.175.

111. WebLogo 3. http://weblogo.threeplusone.com/. Accessed 23 June 2021. 
112. Hall TA. BioEdit: a user-friendly biology sequenc alignment editor and analysis program for Windows 95/98/NT. In: Nucleic acids symposium series. London: Information Retrieval Ltd.; 1999. p. 95-8.

113. Kumar S, Stecher G, Li M, Knyaz C, Tamura K. MEGA X: molecular evolutionary genetics analysis across computing platforms. Mol Biol Evol. 2018;35(6):1547.

\section{Publisher's Note}

Springer Nature remains neutral with regard to jurisdictional claims in published maps and institutional affiliations.
Ready to submit your research? Choose BMC and benefit from:

- fast, convenient online submission

- thorough peer review by experienced researchers in your field

- rapid publication on acceptance

- support for research data, including large and complex data types

- gold Open Access which fosters wider collaboration and increased citations

- maximum visibility for your research: over $100 \mathrm{M}$ website views per year

At BMC, research is always in progress.

Learn more biomedcentral.com/submissions 